\title{
In this issue - October 2020
}

\section{Serge Savary ${ }^{1}$}

Accepted: 21 September 2020 / Published online: 28 September 2020

(C) International Society for Plant Pathology and Springer Nature B.V. 2020

Plant breeding is vital to ensuring food security, locally to globally. No progress in plant breeding in producing varieties that are adapted locally would be possible without genetic resources. Public gene banks have been created to harbour, conserve, maintain, and distribute genes all over the world. Gene banks have the heavy task of ensuring that genetic diversity is preserved for the future, where climates will have changed, where nutritional needs will have evolved, and where agrosystems will have been transformed. Gene banks are also the repository of history, culture, and traditions, in the form of seeds and DNA. The welfare of public gene banks that can share genetic resources with anyone in need of plant material for breeding purposes is essential. In humanity's capability to adapt to the challenges of population growth, climate change, and nutritional needs, the role of pubic gene banks is paramount.

The October Issue of Food Security starts with a Special Section on Genebanks, co-edited by Conny Almekinders (Editorial Board of Food Security and WUR The Netherlands), Melinda Smale (Michigan State University, USA) and Nelissa Jamora (Global Crop Diversity Trust, Bonn, Germany). This Special Section starts with an Introductory article by Melinda Smale and Nelissa Jamora, titled Valuing genebanks.

A series of articles on the themes follows:

- an economic analysis of the value of gene banks (Douglas Gollin);

- an assessment of the impact of IRRI's gene bank on rice breeding in Eastern India (Donald Villanueva et al.);

- a study on gene flows and genetic diversity in relation with CIMMYT's gene bank (Vanessa Ocampo-Giraldo et al.);

Serge Savary

serge.savary@inrae.fr

1 Institut National de la Recherche Agronomique, INRAE, Auzeville, France
- an example of CIP's potato gene bank on the development of new potato varieties in sub-Saharan Africa (Vivian Bernal-Galeano et al.);

- an assessment of CIAT's bean gene bank in the development of improved bean varieties in Rwanda (Stefania Sellitti);

- a study of the contribution of the World Agroforestry gene bank to agro-forest systems in Kenya (Kavengi Kitonga et al.);

- a study of the role played by gene banks in controlling taro leaf blight in the Pacific through host plant resistance (Sefra Alexandra);

- an illustration of the role of genetic diversity in expanding the size of the genepool of wheat (Hafid Aberkane et al.); and

- an assessment of the meanings of gene banks in a European country (Czechoslovakia; Nik Tyack and Milan Ščasný).

This October Issue of Food Security also includes a series of regular articles:

- Dirk Godenau, Jose Juan Caceres-Hernandez, and Jose Ignacio Gonzalez-Gomez: A consumption-oriented approach to measuring regional food self-sufficiency

- Ifeoma Q. Anugwa, Agwu E. Agwu, and Suresh Babu: Gender-Specific Livelihood Strategies for Coping with Climate Change-Induced Food Insecurity in Southeast Nigeria

- Mequanint B. Melesse, Marrit van den Berg, and Inge D. Brouwer: Metrics to analyze and improve diets through food Systems in low and Middle Income Countries

- Davis Muthini, Jonathan Nzuma, and Rose Nyikal: Farm Production Diversity and its association with Dietary Diversity in Kenya

- Isaac Bonuedi, Kofi Kamasa, Eric Evans, and Osei Opoku: Enabling trade across borders and food security in Africa 


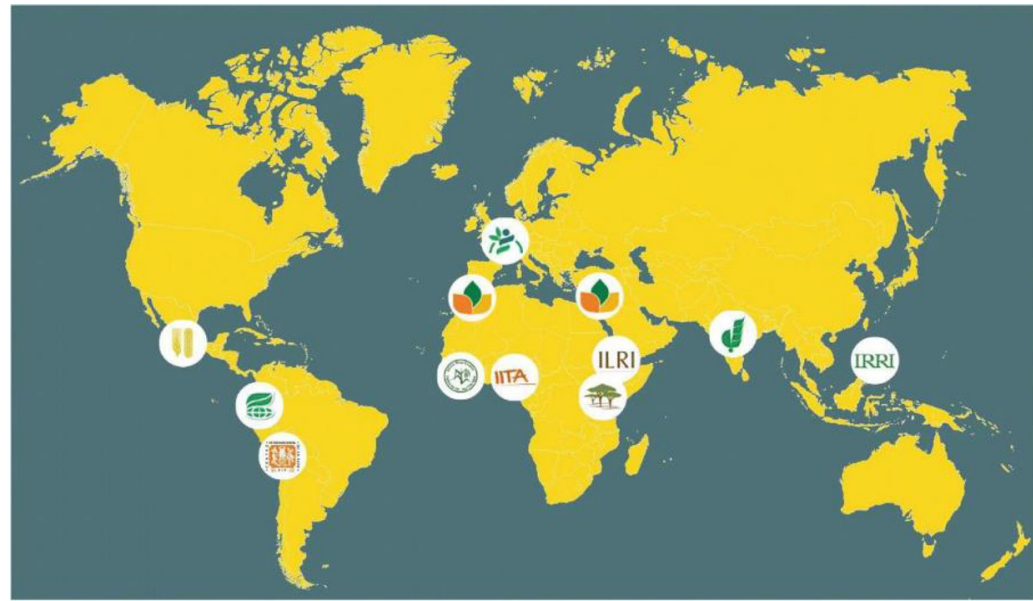

The CGIAR genebanks and where they are located. Source: CGIAR Genebank Platform (2019)- From Smale \& Jamora, 2020, This Issue of Food Security

- Jody Harris, Phuong Hong, Nguyen Phuong, and Nam Huynh: Nutrition transition in Vietnam: changing food supply, food prices, household expenditure, diet and nutrition outcomes

- Nicole M. Mason, Ayala Wineman, and Solomon T. Tembo: Reducing poverty by 'ignoring the experts'? Evidence on input subsidies in Zambia
- Nadjeanny Ingrid Galdino Gomes, Rodrigo Pinheiro de Toledo Vianna, and Rafaela Lira Formiga Cavalcanti de Lima: Nutritional risk, food insecurity and quality of life in people living with HIV/AIDS in Paraiba, Brazil

- Shaosheng Jin, Bashiru Mansaray, and Haoyang Li: Farmers' preferences for attributes of rice varieties in Sierra Leone 